\section{BIBLIOTECA \\ JORGE D. WLLIAMS}

1981 JOURMAL OF HERPETOLOGY 15(2):207-210
COLECCION HERPETOLOGICA

Y BIBLIOTECA

Dr. Jose Miguel Cei

\title{
A New Northern Subspecies of Liolaemus kingi in Argentina
}

\author{
José M. Cei ${ }^{1}$ and José A. Scolaro \\ Departamento de Ciencias Naturales, Universidad Nacional de Rio Cuanto, Cordoba Province, Argentina, and \\ Centro Nacional Patagonico, Puerto Madryn, Chubut Province, Argentina.
}

ABSTRACT-A northermost subspecies of Liolaemus kingi from the isolated Somuncura tableland is described. Its general relationship with the Patagonian Liolaemus kingi group of tropidurine lizards is discussed.

\section{INTRODUCTION}

Patagonian iguanids of the Liolaemus kingi group have been revised by one of us (Cei, 1975). Two related species are at present recognized south of Chubut River (latitude $44^{\circ} \mathrm{S}$ ). The southernmost species, $L$. archeforus Donoso Barros and Cei, embraces two well differentiated dichopatric subspecies. The nominate form is restricted to the basaltic meseta south of the Carrera-Buenos Aires lake and to the surrounding moraines (latitude $47^{\circ} \mathrm{S}$ ). The other subspecies, $L$. archeforus sarmientoi Donoso Barros, was described from the cold, humid regions extending from Lago Argentino (latitude $50^{\circ} \mathrm{S}$ ) to the Strait of Magellan. The northernmost and widespread species L. kingi (Bell) is scattered from Rio Gallegos to the southern borders of Rio Chubut and northward.

During our recent field work (February 1980) in the Meseta de Somuncurá, Rio Negro Province, northern Patagonia, we found at about $1300-1400 \mathrm{~m}$ of altitude an isolated, rather homogeneous population easily referable to the kingi species group. A detailed examination suggests a close morphological relationship with Liolaemus kingi; however, several significant differences exist in a number of character states, of body shape, lepidosis and coloration. The allopatry and differences between the two populations justify their recognition as separate subspecies. We here name the newly discovered subspecies:

\section{Liolaemus kingi somuncurae subsp.nov.}

(Fig.1)

Holotype.-Museo Zoologico, Florence, Italy (MF) 23821, an adult male from Meseta de Somuncurá, near Lago Raimundo, 1400 m, Rio Negro Province, Argentina, 21 February 1980, J. M. Cei and J. A. Scolaro.

Paratypes.-MF 23822-23826, an adult and a juvenile male, 3 females; University of Kansas Museum of Natural History (KU) 186116-186119, a male and 3 females; J. M. Cei-Diagnostic Collection (JMC-DC) 90, an adult male; all collected with the holotype.

Diagnosis. - A slender form of $L$. kingi, recognizable by smaller size; females larger than males; darker, slightly enlarged head; nostrils nearer tip of snout than eye; dorsal and ventral scales slightly smaller than in kingi kingi; larger hind limb, reaching antehumeral region in males; and different color patterns.

Description of holotype.- Head length less than one fourth body length; head larger than wide, length contained in 16 dorsal scales. Longitudinal and antehumeral folds present. Snout gently rounded; rostral scale almost thrice as wide as high; nasal not in contact with rostral, separated

\footnotetext{
${ }^{1}$ Present address: Rancho Somuncura, Rua Fausto de Figueiredo, Birre, 2750 Cascais. Portugal.
} 

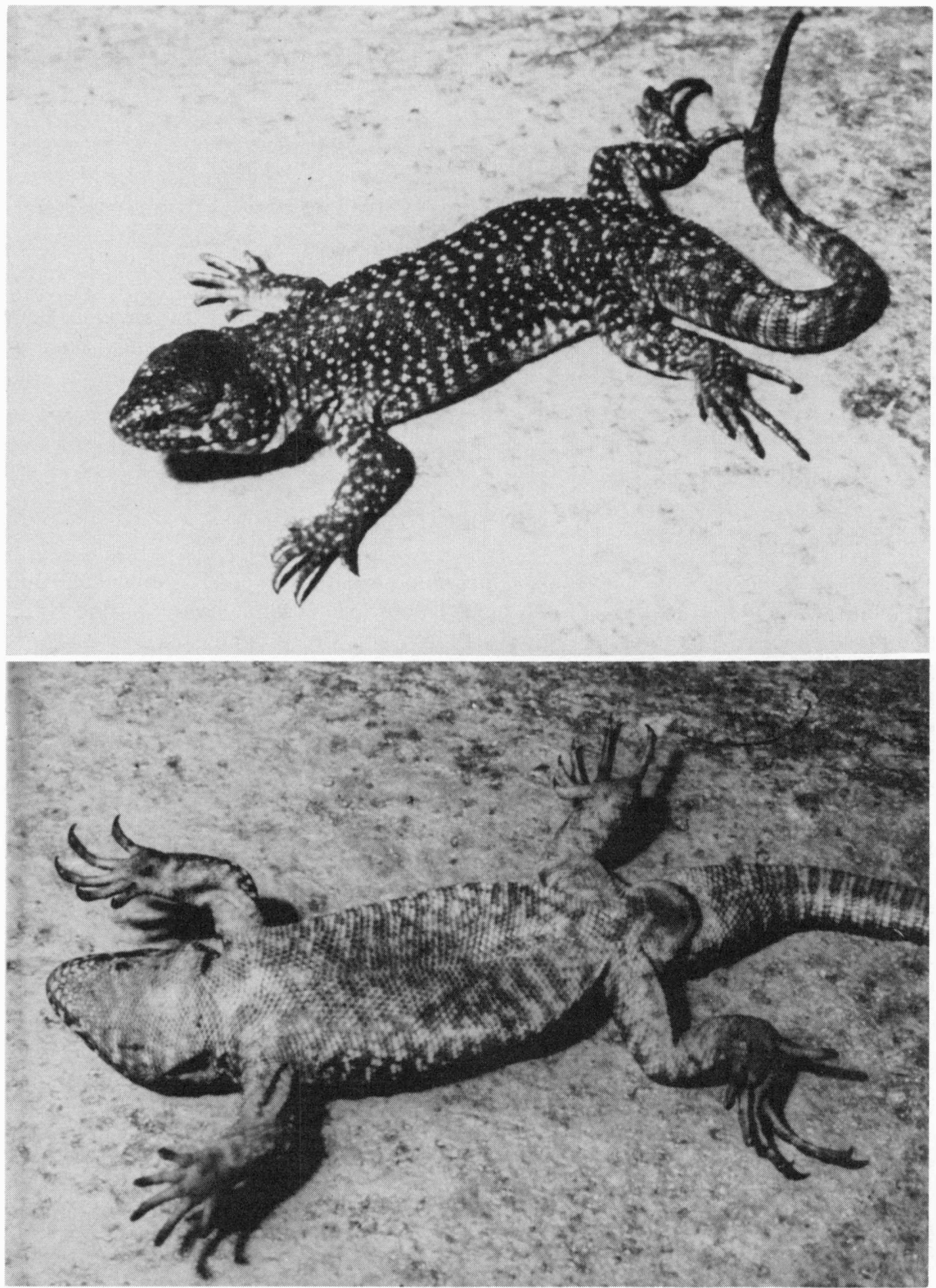

FIGURE 1. Holotype of Liolaemus kingi somuncurae subsp. nov. Top, dorsal view; bottom, ventral view. Slightly enlarged.

from it by two moderately enlarged scales. Nostrils smaller than nasal scale, opening laterally, slightly nearer tip of snout than eye. Ear opening large, oval, edged by few small, conical scales anteriorly. Temporal scales bulky and smooth. Scales of frontal, parietal and occipital regions large, smooth, rather regularly arranged; an azygous frontal. Interparietal scale slightly smaller than parietals. Five large supraoculars, separated from superciliaries by two or three rows of small, 
irregular scales. Subocular scale enlarged, undivided; a single series of scales between labials and subocular; 10 supralabials, 6 infralabials. Mental subtriangular. Eyelid unfringed. Lateral scales on neck small, conical or granular. A row of enlarged white scales on antehumeral fold. Scales across gular region between tympana 42-53. Dorsal scales imbricate, distinctly keeled, not mucronate, almost as wide as long, slightly smaller than ventrals. Lateral scales smaller than dorsals, imbricate, unkeeled; ventrals imbricate, rounded and smooth, somewhat smaller in gular region. Caudal scales strongly keeled, triangular at base of tail, squarish elsewhere; ventral caudal scales subtriangular and smooth, weakly keeled on tip of tail. Number of scales around middle of body 78; subdigital lamellae of fourth finger 19; subdigital lamellae of fourth toe 23-24.

Dorsal scales of fore limb smooth, imbricate; ventrals smaller, smooth, subtriangular or granular. Dorsal scales of thigh and tibia weakly keeled, imbricate; ventrals smooth, rounded, imbricate; granular on thigh posteriorly. A row of enlarged yellow scales on posteroventral border of thighs. Five distinct, bright, orange-colored preanal pores. Hind limb slender, when adpressed reaching antehumeral region. Fourth finger of adpressed fore limb reaching behind middle of body.

Measurements of holotype $(\mathrm{mm})$ : total length 145 ; snout-vent 76 ; head length 15 ; head width 14; fore limb 27; hind limb 42; axilla-groin 38.

Dorsum dark brown, with 14 broken white transverse bars, appearing as a rather irregular line of minute white spots in the holotype. Dorsal surface of limbs dark brown, with irregularly scattered whitish spots or bands. Tail pale brown, with irregular dark and whitish bands dorsally. Belly whitish, with pale brown or gray markings. Femoral and tibial region yellow.

Variation.-Snout-vent length in mm ranges from 62 to 68 in adult males, from 67 to 83 in adult females $(\bar{X} 6=74.75)$. Males are thus smaller than females and males of the nominate form. No sex differences exist in head length and head width, but the fore limbs and hind limbs are larger in males; axilla-groin/hind limb ratios range from 0.78 to 0.90 in males, from 0.92 to 1.04 in females. No sex differences are found in subdigital lamellae of fourth finger (18-21) and fourth toe (23-26), or in number of scales on middle of body (73-85). The number of scales on middle of body averages smaller in males of kingi somuncurae (77-84) than in males of kingi kingi (80-94). No sex differences in color patterns are observed. Broken white transverse bars on dorsum become very irregular lines of white spots in some individuals. Sex maturity is reached from a size of about $60 \mathrm{~mm}$ in males of kingi somuncurae, from a size of about $70 \mathrm{~mm}$ in males of kingi kingi. Both forms are viviparous.

Distribution.-Summit of Somuncurá plateau, from 1300 to $1400 \mathrm{~m}$, Rio Negro province, Argentina.

Etymology.-The name refers to the isolated volcanic tableland where the subspecies is apparently endemic.

Remarks.-Liolaemus kingi somuncurae is an inhabitant of the stony Patagonian steppe covering flat summits of the large basaltic Somuncura meseta. It is mostly active in the summer, from midday to late afternoon, foraging between dense bushes of Stipa speciosa, S. humilis or $S$. tenuis and spiny or cushion plants such as Mulinum, Chuquiraga, Mahihuenia, Verbena, Nassauvia, Lycium, etc. In its biocenotic community Liolaemus elongatus petrophilus, $L$. rothi, $L$. bibroni, $L$. boulengeri and Diplolaemus darwini are also present.

\section{DISCUSSION}

The wide range of Liolaemus kingi is noticeably augmented by the discovery of this new form from Rio negro province, some $250 \mathrm{~km}$ north of the Chubut river. Moreover, the interest of endemic herpetofaunal members of Somuncura plateau is increased by the presence of a Liolaemus species group having a main southern Patagonian or Deseadan distribution like the kingi group. Geographical isolation and beginning speciation of this northernmost population of $L$. kingi probably occurred during some dry glacial phase of the Pleistocene period, leading to expansion of herpetofaunal elements from cooler steppe environments northward. Local climatic features of the 
Somuncurá plateau may explain its survival through interglacial stages, and its morphological differentiation at present.

Some considerations can be made on the reported combination of character states supporting the subspecific status of $L$. kingi somuncurae. Unlike kingi kingi, males of this form are smaller than females. That condition is shown likewise by $L$. archeforus archeforus, but not by $L$. archeforus sarmientoi. Both forms having smaller males are localized on isolated dry, cold volcanic tablelands, such as the Somuncurá and Lake Buenos Aires mesetas. The adaptive meaning of such a character state is difficult to understand. However, it must be emphasized that larger hind limbs, smaller dorsal scales, and similar dorsal color patterns are observed in $L$. kingi somuncurae and $L$. archeforus archeforus, suggesting the independent occurrence of analogous speciation trends in the $L$. kingi group under the selective pressure of similar environmental factors. Different dorsal color patterns between $L$. kingi kingi and $L$. kingi somuncurae were pointed out in the diagnosis of this latter. Liolaemus kingi kingi is pale yellowish or reddish brown on the back, with wider, white or yellow, black bordered transverse bars, often with a conspicuous central spot. Irregular white dots are evident on the flanks and limbs of this form, and the tail is irregularly banded.

We take this opportunity to correct a nomenclatural lapsus in a paper by one of us on species of the kingi group (Cei, 1975). On page 112 (line 2, left) of this work the name Liolaemus archeforus coylensis appears. That name was used in the original manuscript on the form presently named $L$. archeforus sarmientoi. The description of Liolaemus sarmientoi by Donoso Barros (1973) followed submission for publication of the above mentioned manuscript, hence before its publication. Although the name coylensis was removed throughout the review, it escaped correction on p. 112. That usage must be considered as a "nomen nudum" and consequently disregarded.

\section{ACKNOWLEDGMENTS}

We wish to thank J. Asconape of Valcheta, Rio Negro, for his helpful assistance during our field work in the Somuncura region. We are also indebted to O. Sala, Chairman of the Centro Regional Patagonico, Puerto Madryn, Chubut, for his special interest and help in our ecological research in Rio Negro and Chubut. The present work was mostly supported by the aid of the Consejo Nacional Investigaciones Cientificas y Tecnicas, Centro Nacional Patagonico, Puerto Madryn, Chubut, Argentina.

\section{LITERATURE CITED}

Cei, J. M. 1975. Southern Patagonian iguanid lizards of the Liolaemus kingi group. Herpetologica 31:109-116 Donoso Barros, R. 1973. Una nueva lagartija magallanica (Reptilia, Iguanidae). Neotropica 19:163-164. 